\title{
Comparison of results and clinical value of skin prick tests with synthetic and native food allergens in patients at the age of up to 3 years
}

\author{
Ewa Łoś-Rycharska, Anna Sterkowicz, Bartosz Romańczuk, Mieczysława Czerwionka-Szaflarska
}

Department of Pediatrics, Allergology and Gastroenterology, Collegium Medicum in Bydgoszcz, Nicolaus Copernicus University in Torun, Poland

Adv Dermatol Allergol 2016; XXXIII (6): 485-487

DOI: $10.5114 / a d a .2016 .63889$

Skin prick tests are an important diagnostic tool in food allergy, characterized by simplicity and quickness, availability and low cost [1-4]. They can be applied in diagnosis of IgE-dependent reactions $[4,5]$. They are considered to be tools particularly useful in exclusion of IgE-dependent reaction to the tested allergens. Thus, positive results do not allow us to introduce a long-term elimination diet but they oblige us to carry out elimination and challenge tests for verification of diagnosis [3].

Currently, there is no minimal limit at which prick tests would be recommended [1, 6] but they are more difficult to perform in small children [2].

Prick tests with standardized synthetic allergens are most frequently performed, less frequent are tests with allergens in a natural form [6-8]. It seems that tests with native allergens can be a useful supplementation of allergological diagnostic evaluation [5, 7].

It has been argued that tests with native allergens can be more sensitive compared to those with synthetic allergens, for example due to the natural content of substances (e.g. enzymes) which are not contained in extracts of standardized allergens or due to the additives added in the process of food production and processing $[2,5]$. Thus, in some patients we may observe inconsistent results of tests with synthetic and native allergens, though positive results are believed to be more frequent in the case of natural allergens [5].

We compared the results of prick tests with synthetic and native allergens in order to assess clinical usefulness of both these tests.

The study was conducted in the Department of Pediatrics, Allergology and Gastroenterology of Collegium Medicum of the Nicolaus Copernicus University.
Tests were performed in 53 children aged up to 3 years (mean age: $11.99 \pm 9.13$ months). Children presented with symptoms suggestive of food allergy, including atopic dermatitis, gastrointestinal disturbances, or both.

The analysis involved results of 315 test pairs (tests were performed simultaneously with the same synthetic and native food allergens), including 51 with milk, 38 with egg white, 38 with hen's egg yolk, and less tests for each of some other allergens; selecting a set of tests in particular patients was based on the data of their medical history (a possible association of symptoms with an intake of a particular food product). We used standardized allergen extracts by Allergopharma and fresh, raw food products. In interpretation of results we presupposed that a positive reaction is a more severe reaction or equal to half of histamine reaction (the diameter of the wheal was measured), on condition that it was also at least by $3 \mathrm{~mm}$ larger than the negative reaction and the histamine reaction was at least $3 \mathrm{~mm}$ in diameter [1].

A comparison of prick test results with native and synthetic allergens was performed.

In order to verify test results we carried out the analysis of results of elimination and challenge tests conducted in the university outpatient clinic. The data were available only for 36 (67.92\%) patients. The rest of patients did not report.

Consistent results of prick tests with native and synthetic food allergens were obtained in $90.48 \%$ (285/315) of cases. However, taking into account only the patients in whom at least one test was positive, the proportion of consistency was only $36.17 \%$ (17/47). Out of 30 pairs of inconsistent results, the synthetic test was positive more frequently (24 cases). There were no statistically signifi-

Address for correspondence: Ewa Łoś-Rycharska MD, PhD, Department of Pediatrics, Allergology and Gastroenterology, Collegium Medicum in Bydgoszcz, Nicolaus Copernicus University, 9 Skłodowskiej-Curie St, 85-094 Bydgoszcz, Poland, phone: +48 5258548 50, e-mail: klped@cm.umk.pl Received: 23.01.2016, accepted: 20.03.2016. 
cant correlations between test results with synthetic and native allergens vs. sex, age, significant family history or duration and type of symptoms.

Separate analysis of consistency of tests was carried out for cow's milk protein and hen's egg white and yolk. It did not differ statistically between particular food products.

The proportions of consistency of both tests were significantly lower in the analysis of only those patients in whom any of the prick tests was positive. Also, we observed a significant advantage of the allergen of hen's egg white (62.5\% vs. 33.33\%, respectively, for egg yolk and $27.27 \%$ for milk). However, the size of the groups was too small for a reliable statistical analysis. The results are presented in detail in Table 1.

Information about the results of elimination and challenge tests was available for 40 test pairs, out of which at least one was positive. In 27 cases allergy was confirmed. There was no statistically significant difference observed between the accuracy of diagnosis with the use of prick tests with native $(15 / 21,71.43 \%)$ and synthetic allergens (25/35, 71.43\%), $p=0.76$.

Considering only cow's milk, hen's egg white and hen's egg yolk, it was observed that the a statistically significant relation between the prevalence of positive results and the positive result of the challenge test is only valid for the test with a synthetic allergen of cow's milk. Positive results of this analysis are presented in Table 2.
The results of our analysis show that prick tests with native allergens less frequently confirm allergy than tests with synthetic allergens. Calvani et al. [9] showed that the highest negative prognostic value is characteristic of tests with use of fresh milk, and the highest positive prognostic value is characteristic of tests with synthetic casein. In a study by Malinowska et al. [10] it was observed that the percentage of skin prick test positive results with the use of native allergens, performed in 348 children up to 3 years of age, was 16\%. Positive results were observed mainly for hen's egg white and yolk, hen's meat, beef and milk.

Different results were obtained by Gawrońska-Ukleja et al. [7], who carried out tests with fresh fruits and vegetables and obtained more positive results. Perhaps the selection of allergens is significant here (fruits and vegetables only).

In our study there were no statistically significant correlations between test results with synthetic and native allergens vs sex, age, significant family history or duration and type of symptoms. The relation between positive test results and patient's age was described by Schoos et al. [11]. However, their work pertained to inhalatory allergens and compared prick tests with slgE tests. It was observed that the prevalence of positive results of prick tests decreases with the child's age. However, the observation pertained to a larger age range than in our study (6 months- 6 years).

Table 1. Relation between consistency of prick tests with native and synthetic allergens and the type of allergen

\begin{tabular}{|c|c|c|c|c|c|c|c|c|c|c|c|c|}
\hline \multicolumn{2}{|l|}{ Variable } & \multicolumn{3}{|c|}{ All pairs } & \multicolumn{3}{|c|}{ At least one positive } & \multicolumn{5}{|c|}{ Positive result of the prick test } \\
\hline & & \multirow{2}{*}{$\begin{array}{l}\text { All } \\
\text { Sun }\end{array}$} & \multicolumn{2}{|c|}{ Compatible } & \multirow{2}{*}{$\begin{array}{c}\begin{array}{c}\text { All } \\
\text { pairs }\end{array} \\
\text { Sun }\end{array}$} & \multicolumn{2}{|c|}{ Compatible } & \multicolumn{2}{|c|}{ Native allergen } & \multicolumn{2}{|c|}{$\begin{array}{l}\text { Synthetic } \\
\text { allergen }\end{array}$} & \multirow[t]{2}{*}{$P$-value } \\
\hline & & & $n$ & $\%$ & & $n$ & $\%$ & $n$ & $\%$ & $n$ & $\%$ & \\
\hline Milk & & 51 & 43 & 84.31 & 11 & 3 & 27.27 & 4 & 7.84 & 10 & 19.61 & 0.15 \\
\hline Egg whit & & 38 & 34 & 89.47 & 9 & 5 & 55.56 & 5 & 13.16 & 9 & 23.68 & 0.37 \\
\hline Egg yolk & & 38 & 32 & 84.21 & 10 & 4 & 40.0 & 5 & 13.16 & 9 & 23.68 & 0.37 \\
\hline \multirow[t]{3}{*}{$P$-value } & M vs. EW & \multicolumn{3}{|c|}{0.7} & \multicolumn{3}{|c|}{0.41} & \multicolumn{2}{|c|}{0.64} & \multicolumn{2}{|c|}{0.84} & \\
\hline & $M$ vs. EY & \multicolumn{3}{|c|}{0.78} & \multicolumn{3}{|c|}{0.89} & \multicolumn{2}{|c|}{0.64} & \multicolumn{2}{|c|}{0.84} & \\
\hline & EW vs. EY & \multicolumn{3}{|c|}{0.73} & \multicolumn{3}{|c|}{0.83} & \multicolumn{2}{|c|}{0.73} & \multicolumn{2}{|c|}{0.79} & \\
\hline
\end{tabular}

Table 2. Correlation of results of clinical observation with results of allergological tests

\begin{tabular}{|c|c|c|c|c|c|c|c|c|c|c|c|c|c|}
\hline \multirow[t]{3}{*}{ Test } & & \multicolumn{4}{|c|}{ Challenge with milk } & \multicolumn{4}{|c|}{ Challenge with egg white } & \multicolumn{4}{|c|}{ Challenge with egg yolk } \\
\hline & & \multirow[t]{2}{*}{ Sun } & \multicolumn{3}{|c|}{ Confirmation of allergy } & \multirow[t]{2}{*}{ Sun } & \multicolumn{3}{|c|}{ Confirmation of allergy } & \multirow[t]{2}{*}{ Sun } & \multicolumn{3}{|c|}{ Confirmation of allergy } \\
\hline & & & $N$ & $\%$ & $P$-value & & $N$ & $\%$ & $P$-value & & $N$ & $\%$ & $P$-value \\
\hline \multirow{2}{*}{$\begin{array}{l}\text { Native } \\
\text { prick }\end{array}$} & Negative & 30 & 15 & 50 & 0.29 & 21 & 11 & 52.38 & 0.15 & 21 & 10 & 60 & \multirow[t]{2}{*}{1.0} \\
\hline & Positive & 3 & 3 & 100 & & 5 & 4 & 80 & & 5 & 3 & 50 & \\
\hline \multirow{2}{*}{$\begin{array}{l}\text { Synthetic } \\
\text { prick }\end{array}$} & Negative & 27 & 12 & 44.44 & 0.04 & 17 & 8 & 47.06 & 0.28 & 17 & 7 & 41.18 & \multirow[t]{2}{*}{0.41} \\
\hline & Positive & 6 & 6 & 100 & & 9 & 7 & 77.78 & & 9 & 6 & 66.67 & \\
\hline
\end{tabular}


Garriga et al. [12] showed high consistency of test results carried out with synthetic and native allergens (fresh and frozen fruits).

The statistically significant relation between the result of elimination and challenge tests with the use of prick tests with native and synthetic allergens is only valid for the test with a synthetic allergen of cow's milk in our study. In a study by Mowszet et al. [13], it was observed that skin prick tests with the use of native allergens, which were performed for milk and gluten, are characterized by very low sensitivity. A high negative predictive value of tests involving fresh milk was observed by Calvani et al. [9].

In conclusion, consistency of prick test results with synthetic allergens and results of tests with native allergens is not total, especially in the case of positive results. Positive results are more frequent for synthetic allergens. Noticeable differences in sensitivity and consistency with results of challenge tests of the results of the test with synthetic and native allergens for various types of allergens require analysis on a larger group of patients with consideration of a larger number of tests with various allergens in order to identify these differences.

\section{Conflict of interest}

The authors declare no conflict of interest.

\section{References}

1. Mowszet K. Podstawowe zasady diagnostyki i leczenia alergii pokarmowej u dzieci. Nowa Pediatr 2002; 3: 122-7.

2. Wiśniewska-Barcz B, Orłowska E. Testy skórne w diagnostyce alergologicznej. Alergol Współcz 2001; 4: 15-23.

3. Caffarelli C, Dondi A, Povesi Dascola C, et al. Skin prick test to foods in childhood atopic eczema: pros and cons. Ital J Pediatr 2013; 39: 48.

4. Bains $P$, Dogra A. Skin prick test in patients with chronic allergic skin disorders. Indian J Dermatol 2015; 60: 159-64.

5. Rosińska-Więckowicz A, Czarnecka-Operacz M. Skin tests with native alimentary allergens in the diagnostics of food allergy. Post Dermatol Alergol 2009; 26: 270-9.

6. Jaworska J, Zagórska W, Feleszko W. Diagnostyka alergologiczna u dzieci w rożnych grupach wiekowych. Alergol Info 2009; 4: 162-9.

7. Gawrońska-Ukleja E, Ukleja N, Sokołowski Ł, Bartuzi Z. Wartość diagnostyczna testów Prick by Prick ze świeżymi warzywami i owocami w rozpoznawaniu alergii na pokarmy. Współcz Alergol Info 2009; 2: 65-9.

8. Henzgen M, Ballmer-Weber BK, Erdmann S, et al. Skin testing with food allergens. Guideline of the German Society of Allergology and Clinical Immunology (DGAKI), the Physicians' Association of German Allergologists (ADA) and the Society of Pediatric Allergology (GPA) together with the Swiss Society of Allergology. J Dtsch Dermatol Ges 2008; 6: 983-8.

9. Calvani M, Alessandri C, Frediani T, et al. Correlation between skin prick test using commercial extract of cow's milk protein and fresh milk and food challenges. Pediatr Allergy Immunol 2007; 18: 583-8.

10. Malinowska E, Kaczmarski M. Natywne skórne testy pokarmowe jako narzędzie diagnostyczne nadwrażliwości pokarmowej u najmłodszych dzieci. Klin Pediatr 2000; 8: 210-3.

11. Schoos AM, Chawes BL, Følsgaard NV, et al. Disagreement between skin prick test and specific IgE in young children. Allergy 2015; 70: 41-8.

12. Garriga T, Guilarte M, Luengo O, et al. Frozen fruit skin prick test for the diagnosis of fruit allergy. Asian Pac J Allergy Immunol 2010; 28: 275-8.

13. Mowszet K, Matusiewicz K, Iwańczak B. Value of the atopy patch test in the diagnosis of food allergy in children with gastrointestinal symptoms. Adv Clin Exp Med 2014; 23: 403-9. 